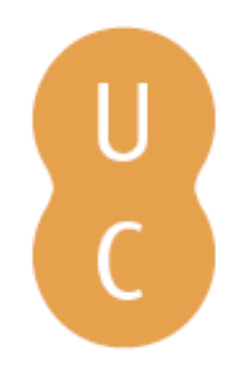

\title{
nombalina
}

\section{A sophos in arms: Plutarch and the tradition of Solon's opposition to the Tyranny of Pisistratus}

\author{
Autor(es): Leão, Delfim F.
}

Publicado por: Imprensa da Universidade de Coimbra; Katholieke Universiteit Leuven

URL

persistente: URI:http://hdl.handle.net/10316.2/32102

DOI: $\quad$ DOI:http://dx.doi.org/10.14195/978-989-26-0462-6_11

Accessed : $\quad$ 26-Apr-2023 05:36:39

A navegação consulta e descarregamento dos títulos inseridos nas Bibliotecas Digitais UC Digitalis, UC Pombalina e UC Impactum, pressupõem a aceitação plena e sem reservas dos Termos e Condições de Uso destas Bibliotecas Digitais, disponíveis em https://digitalis.uc.pt/pt-pt/termos.

Conforme exposto nos referidos Termos e Condições de Uso, o descarregamento de títulos de acesso restrito requer uma licença válida de autorização devendo o utilizador aceder ao(s) documento(s) a partir de um endereço de IP da instituição detentora da supramencionada licença.

Ao utilizador é apenas permitido o descarregamento para uso pessoal, pelo que o emprego do(s) título(s) descarregado(s) para outro fim, designadamente comercial, carece de autorização do respetivo autor ou editor da obra.

Na medida em que todas as obras da UC Digitalis se encontram protegidas pelo Código do Direito de Autor e Direitos Conexos e demais legislação aplicável, toda a cópia, parcial ou total, deste documento, nos casos em que é legalmente admitida, deverá conter ou fazer-se acompanhar por este aviso.

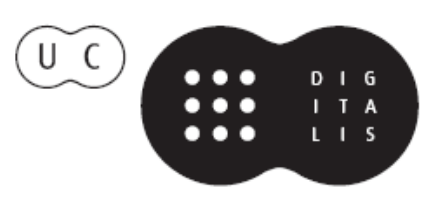




\title{
Puilosophy in Society \\ Virtues and Values in Plutarch
}

\author{
José Ribeiro Ferreira \\ LUC VAN DER STOCKT \\ Maria do Céu Fialho
}

Editors

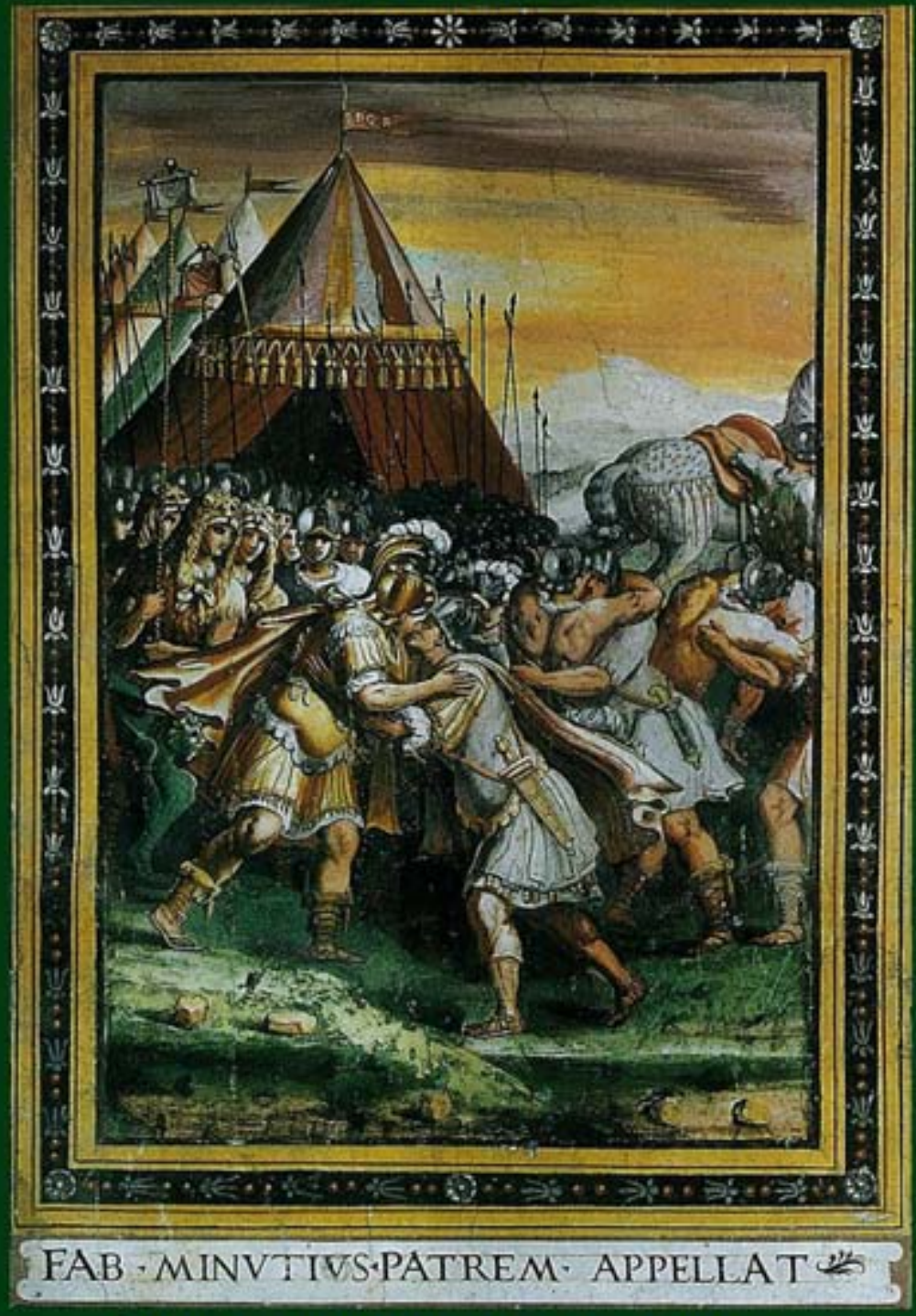

KATHOLIEKE UNIVERSITEIT LEUVEN IMPRENSA DA UNIVERSIDADE DE COIMBRA Leuven-Coimbra, 2008 
(Página deixada propositadamente em branco) 
José Ribeiro Ferreira, Luc van der Stockt \& Maria do Céu Fialho

EDITORS

\section{PhILOSOPHY IN Society}

\section{Virtues and Values in Plutarch}

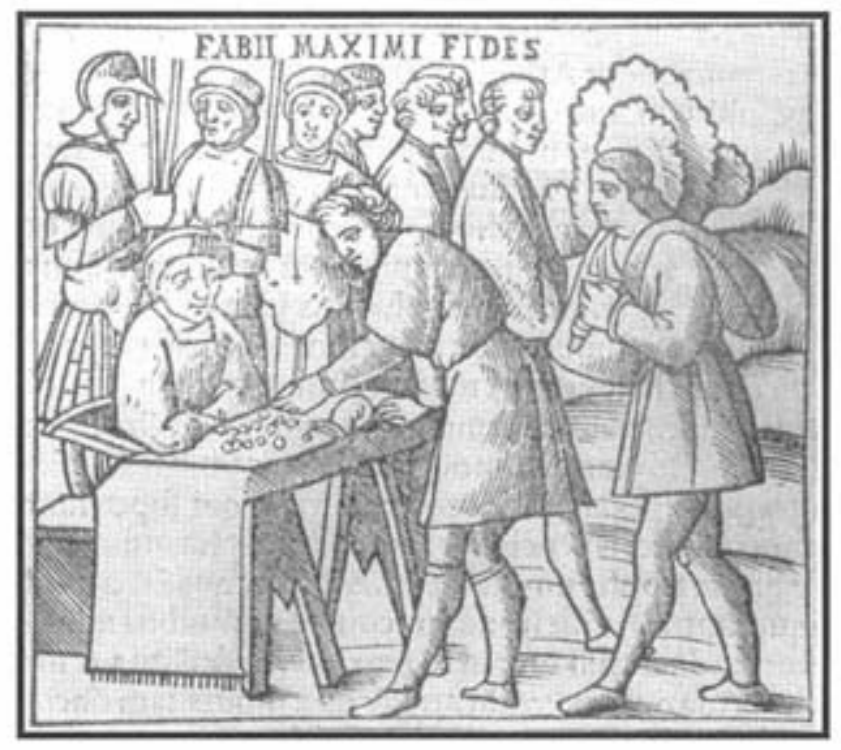

Fabius Maximus' Loyalty

Vitae Plutarchi Cheronei novissime post Jodocum Badium Ascensium longe diligentius repositae maioreque diligentia castigatae, cum copiosiore verioreque indice, nec non cum Aemilii Probi vitis, una cum figuris, suis locis apte dispositis, Venetiis 1516 , fol . 65v

\section{LEUVEN - CoIMBRA \\ 2008}

KATHOLIEKE UNIVERSITEIT LEUVEN

IMPRENSA DA UNIVERSIDADE DE COIMBRA 


\title{
First published 2008
}

\section{(C) Universiteit KATHOlieke Leuven \\ (c) Universidade Coimbra}

\author{
Published by \\ IMPRENSA DA UNIVERSIDADE COIMBRA \\ Imprensa da Universidade de Coimbra \\ Rua da Ilha, $\mathrm{n}^{\circ} 1$ \\ 3000-033 Coimbra (Portugal) \\ Email: imprensauc@ci.uc.pt \\ URL: http://www.uc.pt/imprensa_uc
}

ISBN: 972-989-8074-73-7

Legal Deposit: MA-140-2009

\author{
Printed in Spain by \\ IMAGRAF IMPRESORES, S.A. \\ c/ Nabucco 14 \\ 29006 Málaga \\ Tfno. 952328597
}

\section{Frontispiece:}

Fabius Maximus and Minucius (Francesco da Siena, Grottaferrata, Palazzo Abbaziale). We are grateful to the Archimandrita of the "Monastero Esarchico di Santa Maria di Grottaferrata", P. Emiliano Fabbricatore, for the authorization to reproduce this picture. 


\section{A Sophos in Arms: Plutarch and the Tradition of Solon's Opposition to the Tyranny of Pisistratus

\author{
DeLFiM F. LẼ̃o \\ UNIVERSITY OF COIMBRA
}

\section{Biographical data}

Contrary to what has occurred with other figures, Solon's chronology can be ascertained with a surprising degree of precision, given the relative abundance of informative material. Nevertheless, the evidence conveyed by the sources is at times contradictory, often raising irremediable doubts. However, our objective is not to analyze the full extent of this problem here, but rather, using Putarch's Vita Solonis $^{1}$ as our guide, to take up only those aspects of the problem which accentuate the connection between Solon and Pisistratus. We might start by looking at how the biographer begins his account (Sol. 1.1-2):

In his Response to Asclepiades on Solon's Tables of Law Didymus the Grammarian quotes the remark of a certain Philocles to the effect that Solon's father was Euphorion. However, this contradicts the view of everyone else who has ever written about Solon, because they all without exception say that his father was Execestides, who was, according to them, a man of moderate wealth and political influence, but a member of the most distinguished family in the state, since he was descended from Codrus ${ }^{2}$.

Didymus of Alexandria was a scholar much admired in Antiquity for his erudition and the important work that distinguished him. Plutarch tells us in the text that

1 For a systematic discussion of the biography of Solon, vide LEẢo, 2001, 239-279. We have returned to this study for the inspiration behind some of the arguments contained herein. There is a conspectus of the ancient sources that bear on the relationship between Solon and Pisistratus in MARTINA, 1968, 271-276.

2

To the English version of Plutarch we use the translation made by WATERFIELD, 1998.

José Ribeiro Ferreira, Luc Van der Stockt \& Maria do Céu Fialho (Edd.), Philosophy in Society - Virtues and Values in Plutarch, Leuven-Coimbra, 2008, pp. 155-164. 
Didymus, debating Asclepiades, would have based himself on Philocles, an author whose name only appears in this context and about whose actual existence there is no real proof. In any case, the most important detail here is that this passage offers us the only testimony in the ancient texts which attributes a different name to Solon's progenitor than the one that is usually transmitted by the tradition: Euphorion, a character who is otherwise unknown. This information does not serve, as such, as an alternative to the more commonly known version, according to which the legislator's father is called Execestides ${ }^{3}$.

The social and financial characterization of the family also justifies certain considerations. According to Plutarch, Solon belonged, on his father's side, to a noble family that, considering their economic situation and their area of influence, was part of a kind of "middle class". This circumstance indicates, according to the biographer of Chaeronea, that the future legislator would have needed to dedicate himself, when he was still a young man, to commerce. Aristotle generally agrees with this position ${ }^{4}$. And yet, according to Aristotle, the placement of the reformer among the mesoi politai has to do with reasons that are, by nature, political, which does not preclude the fact that Aristotle may see in Solon's actions the near concretization of the ideal politeia, or, in other words, of a mixed constitution. So, if Execestides belonged to this same stratum of citizens, it would accentuate, in formative terms, the legislator's natural propensity to seek out the middle term. In spite of the personal motivations that would have influenced the two authors, what makes the most sense is to admit, in effect, that Solon was part of a dominant aristocratic oligarchy, since he held the position of archon, at a time in which this magistracy was dependant on birth and possessions. ${ }^{5}$ This could also be a possible explanation for the confidence that aristocrats put in him. However, Solon also merited the countenance of the poorer citizens, a factor which leads us to the hypothesis that he led a life that was somewhat different from that of the majority of noblemen. Lastly, we must bear in mind that at various moments in his own poetry the legislator takes up position at a point intermediary between contradictory forces, which may indicate that the belief that he was a mesos polites could have derived, in the ultimate analysis, from Solon's poetry, a possibility which would stress the tradition's reliability ${ }^{6}$.

E.g. Diodorus, 9.1.1; Lucian, DMort. 20.4; Diogenes Laertius, 1.45. The reference to the authority of Didymus might still provoke some hesitation; in any case, even this possibility is seen to be weakened by the fact that it is not clearly understood if the reputed grammarian agreed or not with his source.

Cf. Ath. 5.3; he follows the same line in Politics (1296al8-21). In order to simplify the exposition, we will consider Aristotle to be the author of the Athenaion Politeia, although this is open to serious doubt.

5

Cf. Aristotle, Ath. 3.1.

6

E.g. frgs. 13 and 15 WEST. 
Continuing with the text we started with, the biographer adds that Execestides was a descendent of Codrus, king of Attica, son of Melanthus, whose lineage went back to Neleus and Poseidon, the founder of the house ${ }^{7}$. The tradition seems relatively belated and perhaps some light is shed upon its origin by the fact that it was Pisistratus who was the first to claim for himself such illustrious ancestors ${ }^{8}$. If this possibility is verified, the ascendancy in question began by being connected only to the tyrant, Solon having been assimilated into it as a result of the preoccupation for bringing together, by a degree of consanguinity, two men who would nevertheless, in the end, opt for opposite political sides. This hypothesis leads us to the question of the legislator's family on his mother's side. In the spirit of clarification, it seems pertinent to us to recall the two paragraphs which follow in Plutarch's biography (Sol. 1.3-4):

As for Solon's mother, Heraclides of Pontus records that she was the cousin of Pisistratus' mother. At first, the fact that they were related made Pisistratus and Solon very close to each other, and another factor was Pisistratus' good looks and youthful charms, because Solon was, on some accounts, in love with him. If so, this would probably explain why later, when they had become political opponents, the hostilities between them were carried out in a spirit free of brutality and ruthlessness; their earlier pacts remained in their minds and, «smouldering with the lingering flame of Zeus' fire» (Euripides, $\mathrm{Ba} .8$ ), preserved the memory of their love and a sense of gratitude.

The author of the Vita Solonis adduces the authority of Heraclides, who establishes a relatively close familial relation between Solon and Pisistratus, on both their mothers' sides ${ }^{9}$. This information is exposed, in a certain way, to the same limitations that we referred to with regard to the ancestors of the legislator, so that the closeness between the two men could be the result simply of the tyrant's political propaganda, or the tendency to connect two figures that belonged to different contexts of Athenian political history. In any case, we should keep open the possibility of the blood relation between the two statesmen, which, if confirmed, would allow us to make important inferences about possible familial alliances in the turbulent period between 600 and $575^{10}$. More dubious, however, is to imagine the possibili-

Cf. Diogenes Laertius (3.1), basing himself on Thrasyllus. Aristotle, however, does not record this connection.

8 Cf. Herodotus (5.65.3-4), together with Diogenes Laertius (1.53). In praising these forefathers, Pisistratus exacts dividends as much on the level of foreign policy (favoring the proximity of the Athenians and the Ionians) as in domestic policy (allowing him to more securely legitimize the tyranny).

Diogenes Laertius (1.49) also speaks, without being specific, of a degree of consanguinity between the two statesmen, based on his reading of Sosicrates, who is a source that inspires a certain confidence.

DAviES, 1971, 323, recognizes that, in genealogical terms, the connection with Pisistratus is relatively strong, but not to the extent that it can be used assuredly to cast a light on the political attitudes of the two men. 
ty that Solon had cultivated an amorous relationship with the future tyrant. Plutarch does not give any clear clues as to whether or not this view is already contained in Heraclides, whom he had cited a paragraph earlier, though he stresses that other authors have also debated the same subject ${ }^{11}$. The biographer encounters a justification for their deep friendship in the consanguinity (syngeneia) which unites the two men, as well as in the innate qualities and the beauty of the young Pisistratus. However, Aristotle negates the validity of this account, appealing to chronological criteria $^{12}$. His position even shows that the tradition could be anterior to Heraclides himself, and it is not improbable that the idea would have been derived, for example, from laws pertaining to pederastic relationships ${ }^{13}$.

Nevertheless the problem of a possible familial connection between Solon and Pisistratus held an extra interest for the ancients from an ethical point of view, to the extent that there also existed the wide spread tradition according to which Solon had opposed Pisistratus' first attempt to implant tyranny, which implies that, though of advanced age, the old legislator was still alive in $561 / 0^{14}$. There are no substantial reasons for doubting this information, since, in his poems, Solon repeatedly advises his fellow-citizens against the actual threat of tyranny (e.g. frgs 11, 33 West), which shows us, furthermore, that he was correctly reading Pisistratus' maneuvers. However, the ancient testimonies go even further and establish the year of the legislator's death with sufficient exactitude. The only problem resides in the fact that there are two different datings, one furnished by Phanias (the more precise of the two) and the other by Heraclides. Both of them are cited by Plutarch, at the end of the biography of the statesman. (Sol. 32.3):

Anyway, Solon survived into the period of Pisistratus' tyranny - a long time, as Heraclides of Pontus reports, but less than too years, according to Phanias of Eresus. Pisistratus' rule began in the archonship of Comias, and according to Phanias Solon died during the archonship of Hegestratus, which immediately followed that of Comias.

Echoes of this putative relationship can be found in Diogenes Laertius $(1.53 ; 1.66)$ and in Aelian $(\mathrm{VH}, 8.16)$. Vide also BARBU, 1933, 51; VON DER MOHL, 1942, 91-92.

Ath. 17.2. Despite it seeming to us, as it did to Aristotle, that the report has no historical basis, we recognize nevertheless that, in chronological terms, it is not totally impossible, especially given the fact that generally there is a difference in age between the erastes and the eromenos. As to the war over Salamis, it seems probable that both of the statesmen had been involved in the conflict, though at different times. On this problem, vide LEAO, 2001, 250-253.

Vide Plutarch, Sol. 1.6. The biographer seems, in a certain fashion, to want to excuse Solon, by mentioning, directly after (1.7), that Pisistratus had also been Charmus' lover. Though the homoerotic thematic is hardly significant in the legislator's poetry, some echoes still appear, though they seem to be more the result of literary convention than of real passions; cf. frgs. 24.5-6; 25 WEST. Aristotle, Ath. 14.2; Plutarch, Sol. 30.6; Diogenes Laertius, 1.49; Valerius Maximus, 5.3. 
The fact that Heraclides wants to prolong Solon's life until long after the beginning of Pisistratus' tyranny is not surprising, since he certainly would have wanted to explore the ethical potentialities of the relationship between these two characters who, as possible lovers, had become political enemies ${ }^{15}$. We have already opined upon the dubious reliability of a reading so oriented above. As such, the dating of Aristotle's old student, Phanias, according to which Solon would have died during Hegestratus' archonship, sometime between 560 and 559 , is preferable and much more precise.

\section{A sophos in arms}

Having pondered those elements connected to the relative chronology of Solon and Pisistratus, we would like to reflect a bit more on the belief that the old legislator had promoted a dramatic attempt to resist the advances of tyranny. Following the same line of logic we have used up to now, we will continue to employ, as a guide to the events under consideration, the account that Plutarch gives us (Sol. 30.1-3):

After Pisistratus' self-inflicted wound and the return from exile which had him carried into the city square on a cart, he began to stir up the general populace by claiming that his enemies had conspired against him because of his political views. He was starting to win over a large numbers of people, united by their loudly voiced grievances, when Solon came up to him, stood by his side and said, «Pisistratus, you're not playing the part of Homer's Odysseus correctly. You've disfigured yourself just as he did, but in his case it was to trick his enemies, not to mislead his fellow citizens."

Later, when the people of Athens were ready to take up arms for Pisistratus, they convened a general assembly at which Ariston proposed that Pisistratus should be allowed a bodyguard of fifty club-bearers. Solon stood up and delivered a speech against the motion, in which he went on at length in a similar vein to some lines in one of his poems (frg. 11.7-5-6 West):

For you pay heed to the tongue and works of a subtle man.

Individually, each one of you walks with the steps of a fox,

But when you come together your thinking is vain.

The passage begins by referring to Pisistratus' stratagem, of presenting himself as a victim of an attack so that he might call upon the State to provide him with a personal military escort, which he would later use as a supporting force for taking power. According to Plutarch, Solon quickly intuited Pisistratus' real intentions, accusing him of using the expedient of wounding himself less skillfully than Ulysses had done. In fact, in the Odyssey (4.240-258), Helen had

Heraclides also could have let himself be tempted by a later dating in order to allow for the meeting with Croesus, who came to the throne in 560 . 
described the way in which the hero of Ithaca had entered Troy unnoticed after having disguised himself as a mendicant and having harmed his own body to enhance the authenticity of his clever trick.

The citation, in this very context, of a fragment of the poetry of the legislator reveals itself to be particularly opportune; according to Diodorus $(9.20)$, this poem (which is a bit longer) would have been composed already after the tyranny had been established. In the part that is now transcribed by Plutarch, Solon shows himself to be well aware of what today we might call the psychology of the masses. People tend, when alone, to act with extreme care, as the proverbial proverb of the fox would suggest; but together, citizens are easily transformed into an aboulic and malleable crowd. They let themselves be carried away by the docile character of words and don't see the coup in the making, becoming easily captivated at the hands of an ambitious politician like Pisistratus.

When the tyrant's intentions had finally become quite clear, even then the old legislator's attitude would draw the attention among the few resisters, as Plutarch emphasizes. It is worth citing the complete passage (Sol. 30.4-8):

However, when he saw that the poor were clamorously determined to gratify Pisistratus, while the rich were slinking away to avoid conflict, he walked out of the assembly, remarking that he had more intelligence than the one party and more courage than the other. He meant that he had more intelligence than those who failed to understand what was going on, and more courage than those who could see what was going on, but who were still too cowardly to offer any resistance to tyranny. So the people of Athens endorsed Ariston's motion, but then stopped worrying Pisistratus about the precise number of body-guards he had and let him get away blatantly maintaining and recruiting as many men as he felt like, until in the end he seized the Acropolis.

After this, with the city in chaos, Megacles and the rest of the Alcmaeonidae lost no time in fleeing into exile; Solon, however, despite his extreme old age and his political isolation, appeared in the city square and addressed his fellow citizens. He had two objectives: to berate them for their ill-advised timidity, and to try to rouse them to further action and to urge them not to throw their freedom away. This was also the occasion when he famously said that though it would have been easier for them to have stopped the tyranny early, while it was still fledgling, it was more important and more glorious to eradicate it and destroy it now that it had already grown to maturity. People were too afraid to pay any attention to him, however, so he went back home, took his arms and armour, and put them in the lane in front of his door. «I have played my part," he said. «I have done all I could to help my homeland and the laws.m And from then on he kept himself to himself. He ignored the advice of his friends to go into exile, and wrote poems in which he rebuked the Athenians (frg. 11.1-4 West): 
Your own cowardice is to blame for your wretched lives;

Bear no ill will against the gods for them.

It was you who gave these men guards and made them great,

And that is why base servitude holds you now.

The panorama of fear implanted by the tyrant is portrayed likewise in other sources that deal with Pisistratus' coup d'état, even though the opposition would be felt more among the aristocrats of contrary political factions (such as the one led by Megacles, of the Alcmaeonidae family), because popular support was, quite precisely, one of the sustaining bases of autocratic governments ${ }^{16}$. As we have said above, Pisistratus' coup d'état occurred in 561/0, therefore a period in which Solon must have been around seventy years old, an age which did not permit him to engage himself physically in the defense of liberty; this is how the symbolical gesture of putting his weapons in front of the doorway to his house can be explained, emphasizing the fact that he had already given to his country and its laws all that was in his power to give.

However, a dedicated sophos like the old legislator continued to wield another important weapon, which, indeed, he always used with great efficacy: the word - not only the spoken words which he offered up in the public agora, encouraging his fellow citizens (as he had already done in the past, in connection with events linked to the dispute of Salamis), but also the written words which he left inscribed in his poetry. To illustrate this "political" character of Solon's poetry (in the sense of civically minded poems, geared toward the common cause of the polis), Plutarch now cites the first two distiches of the same frg. 11 West. The first distich highlights the notion that is already foretold in the Eunomia (frg. 4 West). In the initial verses of that elegy, exemplarily illustrative of Solon's ethical thought, the poet portrays his polis as enjoying not only the general benevolence of the gods, but also the special protection of Pallas Athena. Therefore, if the city was enduring overwhelming problems, this was because of the carelessness of the inhabitants themselves. Now in frg. 11, in a clear and unequivocal fashion, Solon once again affirms that the blame for present evils must fall upon the wickedness of his fellow citizens, since it would be wrong to attribute it to the gods. The situation in which the polis found itself was nothing more than an expression of the cause and effect of the thoughtless acts of its politai.

In concluding what he had to say about the last interventions of the old legislator, Plutarch adds some more notes about the general atmosphere which was being experienced at the time in Athens (Sol. 31.1-3);

The reports of Aristotle (Ath. 14.2) and Diogenes Laertius (1.50) generally agree with Plutarch's narration. A discussion of this and other evidence can be found in MANFREDINI-PICCIRILLI, 1977, 275-276. 
Because of these poems people often used to try to set him straight and warn him that he would be put to death by the tyrant. When they asked him what gave him the confidence to be so reckless, he said: «My old age.» Once Pisistratus had gained power, however, he set about winning Solon over; he expressed such admiration for him, showed him such kindness, and sent for him so often, that Solon actually became his adviser and approved of many of his measures. After all, most of Solon's legislation remained intact under Pisistratus, who not only led the way in abiding by the laws, but also insisted on his associates doing so as well.

Once again, what stands out in the narrative is the indomitable character of Solon, as well as his capacity for transforming a weakness to his advantage, realizing that his old age was his major ally against the risk of retaliation on the part of Pisistratus. It is not improbable that this declaration has some historical value, as it squares with principles upheld in the statesman's poetry, such as the well known idea that age brings with it intellectual development, which is expressed in exemplary fashion in frg. $18 \mathrm{West}^{17}$. As much again could possibly be said in relation to the constitutional reform and to the legislation implemented by Solon, which Pisistratus seems to have maintained without serious alterations, though now under his own guardianship ${ }^{18}$. However, the information that the tyrant had treated Solon with especial affability is more doubtful, insofar as it seems to belong more to the domain of exaggerated speculation, much as the idea, which we have commented on above, of a possible amorous relationship between the two politicians.

Throughout his life, Solon intervened at different times in the Athenian political scene, usually against a backdrop of great instability. Such was the case, for example, when he found a way to skirt legal impediments and to exhort his fellow citizens to recapture their own self-esteem and to once again take up the dispute over the island of Salamis, or even in the way in which he revived the society, the politics and the economy of Attica, sponsoring a profound legislative reform, which would affect all the different sectors of Athenian life. The image of a serious statesman, together with the acquaintance of exceptional individualities, which he had met (in life or in fiction) during the long voyage that he set out on after his archonship, would have contributed to making Solon a very popular figure and helps to make the tradition believable that he would have energetically, though without success, opposed the implementation of tyranny in Athens. The way in which he did it, as well as the symbolism which went along with some of his gestures, helped in creating consistency in the image of the sophos, that same image posterity would use

Frgs. 20 and 21 WEST also contribute to this same universe of values, contrary to the dominant spirit of the poets of the Archaic Period. 
to immortalize him, turning him into one the most paradigmatic and interesting personalities of the cycle of the Seven Sages.

\section{REFERENCES}

BARBU, N. I.,

- Les procédés de la peinture des caractères et la vérité historique dans les biographies de Plutarque, Strasbourg, 1933.

Davies, J. K.,

- Athenian Propertied Families. 600-300 b.C., Oxford, 1971.

LEÂO, D. F.,

- Sólon. Ética e política, Lisboa, 2001.

MANFREDINI, M. \& PICCIRILLI, L.,

- Plutarco. La vita di Solone, Milano, 1977.

MARTINA, A.,

- Solon. Testimonia veterum, Roma, 1968.

MOHLL, P. VON DER

- "Antiker Historismus in Plutarchs Biographie des Solon", Klio, 35 (1942) 89-102.

WATERFIELD, R.,

- Plutarch Greek Lives, Oxford, 1998.

WEST, M. L.,

- Iambi et elegi Graeci ante Alexandrum cantati. vol. II, Oxford, 1992. 


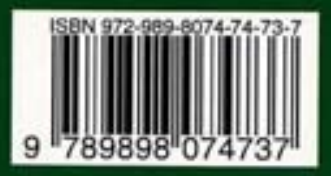

